\title{
PELATIHAN STORYTELLING: MEMBANGKITKAN POTENSI DAN BAKAT UNTUK PRESTASI BERKARYA KEMAMPUAN BAHASA INGGRIS SISWA
}

\author{
Hastuti Retno Kuspiyah ${ }^{1 *}$ dan Ainur Rohmah² \\ 1,2 Program Studi Pendidikan Bahasa Inggris STKIP Nurul Huda Sukaraja \\ *retno@stkipnurulhuda.ac.id
}

\begin{abstract}
Abstrak
Tujuan kegiatan ini adalah : 1) Memberi pelatihan bagi para siswa untuk memahami teori tentang storytellig, menyeleksi cerita, memodifikasi cerita dan bahkan membuat cerita sendiri dan kemudian menceritakanya didepan umum dengan baik dalam bahasa Inggris. 2) Membekali para siswa untuk memiliki pengetahuan tentang teori storytelling yang baik dan dapat memparktikanya didepan umum, khususnya untuk mengikuti Festival dan Lomba Seni Siswa Nasional (LFS2N) tahun 2016. Kegiatan ini berlangsung selama dua minggu, yaitu dari tanggal 02 Mei sampai dengan 16 Mei 2016. Lama waktu yang dibutuhkan ini terkait dengan alokasi waktu yang disediakan oleh pihak sekolah dalam rangka mempersiapkan untuk mengikuti penyelenggaraan FLS2N tahun 2016. Kegiatan ini ada dua bagian yaitu teori dan praktik, namun praktik akan lebih dominan. Peserta pelatihan adalah kelas VII dan VIII dengan pertimbangan bahwa merekalah nantinya yang akan disiapkan untuk terlibat dalam mengikuti lomba storytelling. Namun jumlah peserta dibatasi 20 siswa yang diambil dari perwakilan diawal dari masingmasing kelas dengan pertimbangan akan terjadi sharing dengan siswa lain dikelas. Berdasarkan hasil kegiatan, dapat disimpulkan bahwa kegiatan ini merupakan kegiatan baru bagi para peserta dan mereka terlihat antusias dengan merespon positif dalam bentuk selalu menghadiri jadwal kegiatan yang telah di rencanakan secara rutin. Walaupun terlihat mengalami banyak kesulitan dalam melakukan storytelling dikarenakan keterbatasan dalam menggunakan Bahasa Inggris.
\end{abstract}

Kata kunci: Storytelling, Bahasa Inggris, pelatihan.

\section{PENDAHULUAN}

Pendidikan di Indonesia mengarah kepada pembentukan manusia seutuhnya. Diantaranya pembentukan budi pekerti, jati diri, sikap dan mental terpuji yang berakar dari nilai- nilai bangsa. Sebagaimana isi pidato Trisakti tahun 1963 oleh presiden pertama Republik Indonesia, Ir. Soekarno yaitu: 1) berdaulat secara politik, 2) berdikari secara ekonomi, dan 3) berkepribadian secara sosial budaya. Demi mewujudkan tujuan tersebut, maka dalam pendidikan terangkum 3 unsur, seperti pengetahuan ( Knowledge), keterampilan (Skill), dan sikap (Atittude) yang terpadu dalam kreativitas dan kepribadian peserta didik.

Merujuk kepada pengaplikasian isi Trisakti, kesenian merupakan salah satu unsur pendorong pertumbuhan dan perkembangan dalam berbagai aspek kehidupan. Dengan mendayagunakan kesenian secara selektif dan baik maka ini akan meningkatkan kesejahteraan melalui pemberdayaan ekonomi kreatif. Kesenian merupakan wahana untuk mengekspresikan diri sesuai dengan tuntutan ilmu pengetahuan dan teknologi. Sedangkan pendidikan dan bahasa adalah dua elemen yang tidak dapat dipisahkan sebagai media komunikasi dalam menyuarakan makna kehidupan. Dengan menyemarakkan kegiatan berkesenian dalam pendidikan, peserta didik diharapkan mampu mengasah kepekaan hati dan nuraninya yang dimana kelak dapat memperhalus budi pekerti dan tingkah lakunya.

Dalam upaya memberikan ruang bagi kreativitas dan potensi para siswa SMP, Kemenetrian Pendidikan dan Kebudayaan menyelenggaraka Festival dan Lomba Seni Siswa Nasional (LFS2N). Seperti halnya sekolah- sekolah menengah pertama lain di Kabupaten OKU Timur dan kota besar di Indonesia, SMP Muhammadiyah 1 Rawabening berbenah diri dalam rangka untuk melakukan persiapan yang baik dalam menghadapi penyelenggaraan Festival dan Lomba Seni Siswa Nasional (LFS2N) tahun 2016. Salah satu cabang lomba yang akan diikuti adalah lomba kreativitas bercerita Bahasa Inggris (storytellig). Sudah menjadi komitmen sekolah tersebut untuk membekali siswanya 
dengan persiapan yang baik dalam rangka mengikuti penyelenggaraan Festival dan Lomba Seni tersebut sehingga mereka diharapkan mampu menjadi juara atau paling tidak dapat membangkitkan potensi dan bakat mereka sebagai warga masyarakat yang memperlihatkan prestasi berkarya, sekaligus menjadi kebanggaan sekolah dan dunia pendidikan. Untuk mendukung dan mencapai tujuan tersebut, pihak sekolah melakukan kerjasama dengan Program Studi Pendidikan Bahasa Inggris STKIP Nurul Huda untuk melakukan pembinaan dan pelatihan storytelling.

\section{KHALAYAK SASARAN}

\section{METODE/EKSPERIMEN}

Khalayak sasaran dalam kegiatan ini adalah siswa kelas VII \& VIII SMP Muhammadiyah 1 Rawabening OKU Timur, dengan jumlah 20 siswa.

\section{METODE PELAKSANAAN}

Nama Kegiatan : Pelatihan storytelling

Kegiatan ini akan dilaksanakan selama dua minggu pada kelas VII \& VIII SMP Muhammadiyah 1 Rawabening OKU Timur, dengan jumlah 20 siswa. Dimulai tanggal 02 Mei s.d 16 Mei 2016.

\section{AGENDA PELAKSANAAN KEGIATAN}

Kegiatan pelatihan dilaksanakan selama dua minggu, yaitu dari tanggal 02 Mei s.d 16 Mei 2016. Adapun rincian jadwal pelaksanaan adalah sebagai berikut:

Tabel 1. Jadwal Pelaksanaan

\begin{tabular}{|c|l|c|c|l|}
\hline No & HARI/ TANGGAL & WAKTU & MATERI & NARASUMBER \\
\hline 1 & Senin, 2 Mei 2016 & $13.00-13.15$ & Pembukaan & Ainur Rohmah \\
\cline { 3 - 5 } & $13.15-15.00$ & $\begin{array}{c}\text { Pengenalan \& } \\
\text { Penyampaian Materi }\end{array}$ & Hastuti Retno K \\
\hline 2 & Sabtu, 7 Mei 2016 & $13.00-15.00$ & Modelling \&Latihan 1 & $\begin{array}{l}\text { Hastuti Retno K } \\
\text { Ainur Rohmah }\end{array}$ \\
\hline 3 & Selasa, 10 Mei 2016 & $13.00-15.00$ & Modelling \&Latihan 2 & $\begin{array}{l}\text { Hastuti Retno K } \\
\text { Nurul Fadilah }\end{array}$ \\
\hline 4 & Sabtu, 14 Mei 2016 & $13.00-15.00$ & Praktik & $\begin{array}{l}\text { Hastuti Retno K } \\
\text { Nurul Fadilah }\end{array}$ \\
\hline 5 & Senin, 16 Mei 2016 & $13.00-14.30$ & Evaluasi & $\begin{array}{l}\text { Hastuti Retno K } \\
\text { Nurul Fadilah }\end{array}$ \\
\cline { 3 - 5 } & & $14.30-15.00$ & Penutup & $\begin{array}{l}\text { Ainur Rohmah } \\
\text { Hastuti Retno K }\end{array}$ \\
\hline
\end{tabular}

\section{PROSES PELAKSANAAN}

Sedangkan materi dirancang berdasarkan permintaan pihak sekolah dan khususnya merujuk kepada Festival dan Lomba Seni Siswa Nasional (LFS2N) tahun 2016. Kegiatan ini ada dua bagian yaitu teori dan praktik, namun praktik akan lebih dominan.

Peserta pelatihan adalah kelas VII dan VIII dengan pertimbangan bahwa merekalah nantinya yang akan disiapkan untuk terlibat dalam mengikuti lomba storytelling. Namun jumlah peserta dibatasi 20 siswa yang diambil dari perwakilan diawal dari masing- masing kelas dengan pertimbangan akan terjadi sharing dengan siswa lain dikelas.

Dalam pelaksanaannya, tim menjelaskan tentang teori- teori bercerita Bahasa Inggris dan menenkankan pentingnya dan bernilainya kegiatan bercerita yang sesungguhnya sangat dekat dan tidak dapat dipisahkan dengan kehidupan manusia. Selain itu, hal lain yang penting adalah dalam bercerita bukan menghafalkan karena cenderung lupa dan tidak hidup. Dan yang terpenting mereka mampu memahami plot dan alur cerita serta kemudian mampu untuk memodifikasinya, karena semua cerita yang ada ketika diceritakan tidak akan sama satu dengan yang lainya.

\section{TIM PELAKSANA}

Tim pelaksana kegiatan ini terdiri dari dua (dua) dosen Program Studi Bahasa Inggris dan seorang mahasiswa Program Studi Bahasa Inggris semester enam. Nama-nama dosen dan mahasiswa tersebut seperti yang tercantum dalam lembar Tim Pelaksana Kegiatan Pelatihan 
storytelling.

Tabel 2. Tim Pelaksana Kegiatan Pelatihan storytelling

\begin{tabular}{clcc}
\hline No & \multicolumn{1}{c}{ Nama } & Jabatan & Keterangan \\
\hline 1 & Hastuti Retno Kuspiyah, M.Pd. & Dosen & Ketua Tim \\
2 & Ainur Rohmah, M.Pd. & Dosen & Anggota \\
3 & Nurul Fadilah & Mahasiswa & Anggota \\
\hline
\end{tabular}

\section{APA ITU STORYTELLING?}

\section{HASIL DAN PEMBAHASAN}

Storytelling memiliki kekuatan untuk merangsang imaginasi dan meningkaatkan kebiasaan membaca dari pendengarnya. Lebih jauh lagi, ini adalah salah satu cara yang baik untuk pembelajaran anak usia $6-12$ tahun. Diharapakan melalui storytelling dapat emngembangkan ketrampilan mendengar sebagai salah satu komponen bahasa. Scoot and Ytreberg (1993: 29) menyatakan bahwa bercerita untuk anak untuk semua tingkatan atau umur dapat diartikan bahwa kamu dapat mengubah bahasa sesuai tingkatan mereka, kamu dapat mengulangi kembali, kamu dapat mengekspresikan dongeng dengan bahasa tubuh, dan kamu dapat bertatap langsung dengan mereka. Ini berarti bahwa melalui storytelling dapat membantu siswa untuk belajar kosa kata, mempengaruhi tindakan dan prilaku sekaligus karakter mereka secara alami.

Sedangkan menurut Damayanti (2005: 2) menjelaskan bahwa guru yang mengajar anak usia 3 - 11 tahun harus menyadari kekuatan storytelling dalam memperkuat keterampilan pemahaman dalam mendengar, grammar/ structure, penambahan kosa kata dan ekspresi. Ini dapat menjadi alat serbaguna untuk pembelajaran didalam kelas dikarenakan ini merupakan cara belajar dengan kesenangan dan dalam waktu bersamaan mereka sambil belajar. Ini berarti bahwa secara tidak langsung storytelling tidak hanya memberikan suasana yang menyenangkan saat belajar. Sebagaimana yang dinyatakan oleh Cameron (2002: 159) bahwa stories offer a whole imaginary world, created by language, that children can enter and enjoy, learning language as they go.

\section{KRITERIA STORYTELLING}

Berdasarkan Damayanti mempertimbangkan berbagai macam cerita yang akan diberikan kepada anak- anak, menyeleksi cerita yang baik merupakan langkah pertama yang sangat penting. Ini merupakan peranya sebagai pemain/ penyampai pertama dari semua proses mendongeng. Contoh cerita dengan sumber- sumber yang berbeda, yaitu: 1) hikayat, 2) dongeng (cerita yang dibuat- buat), 3) serangkaian gambar komik, 4) cerita binatang, dan 5) kisah nyata.

Semenjak cerita- cerita ini digunakan dalam pembelajaran, cerita- cerita ini harus mempersatukan atau menyatu padukan dengan capaian pembelajaran yang diinginkan. Sebagaimana Kuspiyah (2007: 16) menjelaskan beberapa kriteria untuk cerita yang baik, yaitu:

1. Panjang cerita

2. Macam- macam ekspresi yang digunakan

3. Makna cerita dari permulaan sampai pengakhiran

4. Tampilan buku cerita (warna, gambar dan lay out)

5. Kontek budaya

6. Ukuran buku

7. Tujuan anda

Jadi, berdasarkan penjelasan diatas bahwa tidak semua jenis cerita cocok digunakan dalam proses pembelajaran. Yang mana dalam memilih cerita juga harus berdasarkan kebutuhan dan mampu merangsang ketertarikan siswa atau cerita harus di cek bagaimana pesan moral dan karakter yang ada.

Sedangkan untuk hasil kegiatan pengabdian pada masyarakat mendapatkan sambutan yang positif dari pihak sekolah, terutama karena pelatihan ini sesuai dengan kebutuhan mereka. Motivasi peserta pelatihan cukup antusias. Hal ini menandakan adanya keinginan untuk meningkatkan 
kemampuan mereka dalam penguasaan bahasa Inggris.

Setelah pelatihan selesai diharapkan pihak sekolah melakukan upaya- upaya tindak lanjut untuk meningkatkan kemampuan penguasaan bahasa Inggris terutama storytelling para siswa. Sedangkan hasil yang diperoleh diharapkan dapat memotivasi para siswa dan pihak sekolah untuk selalu meningkatkan kemampuan mereka demi komitemen untuk membekali para siswa yang mampu berdaya saing untuk melanjutkan kejenjang yang selanjutnya. Selain itu, pihak tim pelaksana pelatihan berharap untuk tetap terjalin kerjasama yang lebih baik.

\section{PENUTUP}

\section{KESIMPULAN}

Kesimpulan yang didapat dari kegiatan pengabdian ini adalah:

1. Kegiatan ini merupakan kegiatan yang baru bagi siswa SMP Muhammadiyah I Rawabening OKU Timur.

2. Para siswa merespon positif dengan selalu mengikuti jadwal kegiatan dengan rutin. Selain itu mereka juga sangat antusias mengikuti kegiatan ini meskipun mengalami kesulitan dalam menggunakan bahasa Inggrisnya.

3. Para siswa masih mengalami kesulitan dalam menerapkan teori- teori storytelling, diantaranya: kurang percaya diri, masih lemah dalam membaca dan mengucapkan kata atau kalimat bahasa Inggris dengan baik, serta kurangnya berimaginasi dalam berimprovisasi.

\section{SARAN}

Saran yang diharapkan dari kegiatan pengabdian ini adalah:

1. Pelatihan ini diharapkan ada tindak lanjutnya antara pihak sekolah dan STKIP Nurul Huda Sukaraja terutama Program Studi Bahasa Inggris.

2. Pelatihan cara membaca dan mengucapkan kata- kata serta kalimat bahasa Inggris sangat dibutuhkan.

3. Pelatihan diharapkan untuk memiliki waktu yang cukup.

\section{UCAPAN TERIMAKASIH}

Dalam bagian ini kami mengucapakan terimkasih kepada Tim pelaksana kegiatan pengabdian kepada masyarakat atas kerjasama yang baik. Demikan juga terhadap kepala sekolah selaku pihak yang memberikan wewenang atas terlaksananya kegiatan ini. Dilain pihak kami memberikan ucapan terimaksih kepada pihak Lembaga Penelitian dan Pengabdian kepada Masyarakat dan civitas akademika STKIP Nurul Huda yang telah membantu dari mulai konsep pengabdian sampai proses penulisan artikel.

\section{DAFTAR PUSTAKA}

Cameron, L. 2001. Teaching English to Young Learners. Cambridge University Press

Ellis, G \& J. 1991. The Storytelling Handbook: A Guide book for primary teachers of English. London Pinguin Book.

Kuspiah, Hastuti Retno. 2006. A Comparative Study between using Storytelling and Reading Text in Teaching Vocabulary Mastery at the Fifth Grade students of SD N II Rawa Laut Bandar Lampung. STKIP- PGRI Bandar Lampung.

Wright, A. 2003. " the Place of Story in ELT in A, Paran \& E, Watts(eds) Storytelling in ELT. Kent: IATEFL Publications, 7-10. 